\title{
THE REAL PERIODIC POPULATION GROWTH AS A BASE FOR DETERMINING THE DEGREE OF EXPLOITATION OF GREY PARTRIDGE (Perdix perdix L.) POPULATIONS IN MACEDONIA AND COMPARATIVE ANALYSIS OF OTHER METHODS USED
}

\author{
Maletić V. ${ }^{1}$, Kolevska D. D. ${ }^{1}$, Lavadinović V. ${ }^{2}$, Beuković D. ${ }^{3}$, Stojčevski D. ${ }^{4}$
}

Summary: In wildlife management it is crucial, especially for small game, to determine the real periodic populations' growth, i.e. the changes in populations densities during one reproductive period (from reproduction to hunting season). This particularly refers to the area of R. Macedonia, where the grey partridge was and still is the main and the most numerous species of small game per total hunting, and also the most attractive game offered in hunting tourism, so that the hunting grounds managers, in their desire for quick profits, usually do not take care about the pesmissible shooting that would correspond to the real situation of its population in the field, which might lead to catastrophic consequences.

Therefore, researches were conducted during the period 2007-2014 in experimental hunting ground of Faculty of Forestry in Skopje named "Trubarevo", which covers 450 ha of typical biotope for grey partridge. Data were collected through complete censuses which were conducted at least three times per week. Spring density (Sed), respectively a number of breeding pairs, was determined during period 15 February - 15 March, while an autumn density (Aed) was estimated after harvesting of the most of crops and the completion of the morphological development of the raised youth, i.e. from 10 September to 10 October every year.

Real periodic population growth (Rpg) was calculated as a difference between two censuses (the autumn and spring density during the same year), but it ignores adult individuals' mortality. Coefficient of real periodic growth per unit of breeding stock (Crpg) was calculated as a quotient between the real periodical growth and spring ecological density.

The average value of the spring ecological density, that is, the number of breeding pairs per 100 ha in the micropopulation of grey partridges in the hunting ground Trubarevo, in the period 2007-2014, amounted to 8.89 (4.89 - 11.78), while the average real periodic growth per the same area amounted to 23.81 (7.11 - 34.44).

The coefficient of the real periodic growth has been determined at 1.41, and varied within a wide range from $0.53-2.98(\mathrm{CV}=52.47 \%)$.

There are no universal standards for determining the real periodic growth of grey partridges populations or micropopulations, considering the variability of this element of population dynamics in space and time, as a result of differences in the dynamics of this species populations in different ecological conditions, in different parts of its areal and in different time periods. Calculating the real periodic growth in order to find the degree of exploitation of the micro population, must,

\footnotetext{
${ }^{1}$ Maletić Vladimir, PhD, professor, Kolevska Dana Dina, PhD, professor, Ss. Cyril and Methodius University in Skopje, Faculty of Forestry, Skopje, Macedonia

${ }^{2}$ Lavadinović Vukan, MSc, University of Belgrade, Faculty of Forestry, Belgrade, Serbia

${ }^{3}$ Beuković Dejan, PhD, assistant professor, University of Novi Sad, Faculty of Agriculture, Novi Sad, Serbia

${ }^{4}$ Stojčevski Dejan
}

Corresponding author: Maletić Vladimir, e-mail: vmaletic@sf.ukim.edu.mk 
therefore, be made each year for every micropopulation. This conclusion imposes the need for constant monitoring of the most important structural elements (density and real periodic growth as a result of birth and death rates), in order to determine the degree of rational use. And the rational exploitation of grey partridges populations and micro populations is one of the most important forms of their protection in the worsening ecological conditions, and the only one that is fully and exclusively in the hands of the hunters.

Key words: grey partridge, population dynamic, real periodic population growth, coefficient of real periodic growth.

\section{Introduction}

Vulnerability and the reduction of the number of partridges (Perdix perdix L.) is a global process which in the last few decades got alarming proportions (Aebischer, et al. 1997). Since the 1950s, it has declined across Europe (Burfield \& van Bommel 2004), amounting to 82\% since 1980 (PECBMS, 2011) In the UK the number of grey partridges has declined by over $90 \%$ since the mid-1960s (Baillie et al. 2009, Risely et al., 2011), resulting in the species appearing on the Red List of Birds of Conservation Concern (Eaton et al., 2009). In the Czech Republic from 1965 until the late eighties - even up to 95\% (Štasny et all., 1997), and the situation is similar in Poland (Panek, 2000, 2006), Hungary (Faragó, 1988; Báldi \& Faragó, 2007) and many other countries of Europe. The situation is not much different on the Balkan Peninsula as well. The percentage of harvested grey partridges in the Republic of Serbia in the mid-seventies was over $28 \%$ compared to the parent fund (Popović \& Gajić, 1996), however, even though the same was reduced to only $2,58 \%$, the downward trend in population numbers has not been eliminated (Popović et all., 2008). In Vojvodina, the numerical strength of the partridge population in 1991 fell to only 25.29\% compared to 1966 (Beuković \& Marinković, 1997). The situation is similar at several typical locations in Macedonia (Maletić, unpublished data), except that on certain parts of its areal the situation of this species population is at a satisfactory level.

The suggested reduction of shooting bags (Birkan \& Jacob, 1988; Potts \& Aebischer, 1995) or suspension of hunting does not solve the problem of decreasing population number (Farago, 1996; Bro et al. 2000; Aebischer \& Ewald, 2010). Neither the supplementation and (re)introduction of artificially produced birds, according to the researches made in Italy (Meriggi et al., 2002) and in R. Croatia (Tomljanović et al., 2013), do not provide satisfactory results, and in some cases can cause even the opposite the effect in terms of decreasing the productivity of wild populations (Putaala \& Hissa, 1998).

The reasons for this trend are numerous, directly caused, and most often difficult or impossible to eliminate. The problem lies in the two, often conflicting and mutually exclusive attitudes: the utilization and changing of its habitat in order to increase the yield of agricultural crops grown on them, and on the other side - their protection (Maletić, et al. 2012).

Three main causes of decline were identified, linked to agricultural intensification (Aebischer \& Ewald, 2012):

(1) destruction of nesting habitats, resulting in impoverished capacity of the biotope;

(2) pesticide-induced reduction in animal-food (insects) in the crops, leading to poor chick survival; and

(3) increased predation pressure on remaining habitat, leading to adult and nest losses.

The studies of grey partridge population dynamics are directly induced by the needs of the hunting management, especially in the current, worsening environmental conditions in their habitat, with the aim of determining the degree of sustainable exploitation of its population, which is only and exclusively in the hands of hunters and organizations that manage the hunting grounds. 
The bioecology studies for every kind of game require registration of the population dynamics basic elements, i.e. density and real population growth and its factors (Maletić et al., 2012). Namely, the population, as a dynamic category, is exposed to permanent changes in its size and internal composition in the function of time. Changes in density are the result of a number of factors, among which the birth rate and mortality have the greatest significance.

Therefore, the real growth of the population is a function of birth and death rates of individuals within this population, adjusted by the balance of migration flows (emigration immigration) in a given period.

For the hunting science and practice, it is of utmost importance for the game management, especially for the small game, to determine the real periodic growth, or changes in the density of the population during a reproduction period (from the start of reproduction - until the beginning of the hunting season). This particularly refers to the area of R. Macedonia, where the grey partridge was and still is the main and most numerous species of small game per total hunting, and also the most attractive game offered in hunting tourism, so that the hunting grounds managers, in their desire for quick profits, usually do not take care about the permissible shooting that would be corresponding to the real situation of its population in the field, which might lead to catastrophic consequences.

\section{Material and Methods}

This study was conducted in the period 2007 - 2014 in the experimental hunting ground of the Faculty of Forestry in Skopje named "Trubarevo" on an area of 450 ha, as a typical biotope for this game species. It is the smallest by surface (1475 ha), and the only non-commercial hunting ground in the Republic of Macedonia intended for educational - scientific objectives. It is located in the southeastern part of the periphery of the city of Skopje, bordered by the suburbs and the most densely populated city municipality. It's a typical lowland hunting ground with an altitude of 235 to 240 meters and represents the bottom of the former expanded riverbed of Vardar river, now covered with young alluvial deposits. The natural conditions of the habitat and the mosaical fragmentation - mixed arable land of planted crops, are optimal for the partrige survival. Different crops, as cereals (wheat, barley and corn), garden cultures (tomatoes, peppers, potatoes, carrots, etc.) and melons, take each approximately $15 \%$ of the total area. Clover and riverside vegetation (brushwood and shrubs) cover approximately 2.5\% each, orchards 20\%, and the remaining 30\% of the area are uncultivated and weedy fields. The land belongs exclusively to small owners, bordered by hedges for the most part (80\%), with lots of 0.1 to 0.3 ha, $10 \%$ of 0.3 to 1 ha, while only $10 \%$ are larger than 1 ha.

Data collection was performed using the method of total counting, more precisely, by monitoring the population density at least three times a week. Spring density, or the number of breeding pairs, was established in the period 01.03. - 15.03., and autumnal density - after harvesting of the largest part of the crops (c/a 90\%) and the completion of morphological development of the offspring, or from 20.09. to 10.10. each year. The counting was conducted with 3 to 4 participants and 2 hounds - pointers of excellent quality. The term "monitoring the numerical strength" means permanent presence at the hunting ground throughout the year, usually 3-5 times a week, which allows the registration of all changes in population size, except in the months of raising offspring (from early May to late July). Considering the small hunting-productive area of hunting grounds (450 ha), the structure of arable fields, visibility of the terrain and the relatively small number of flocks (10-25) in autumn, the counting carried out in this way allows very precise data, even about 
the smallest changes in population density, i.e. it almost completely eliminates any errors in counting in terms of double-counting of individual flocks.

For all the time of the research no reduction of grey partridges natural predators was conducted, nor regular shooting was carried out, and the individual shooted specimens were taken into account when making calculations.

The real periodic growth was calculated as the difference between the two countings (autumn and spring density in the same year), deliberately ignoring the possible mortality of adult animals, using following equation:

$$
\text { Rpg }=\text { Aed }- \text { Sed }
$$

The coefficient of the real periodic growth per unit of the breeding stock was calculated by following formulas:

$$
\begin{aligned}
& \text { Crpg }=\frac{\text { Aed }- \text { Sed }}{\text { Sed }}, \\
& \text { Crpg }=\frac{\text { Rpg }}{\text { Sed }}, \quad \text { where }
\end{aligned}
$$

Crpg - Coefficient of the real periodic growth;

Aed - Autumn ecological density;

Sed - Spring ecological density;

Rpg - Real periodic growth

These abbreviations were used in the following tables and figures.

For statistical data processing we used the program SPSS for windows, version 17.0. The relationship between spring ecological density (Sed) and the coefficient of the real periodic growth was calculated using the Pearson's correlation coefficient.

\section{Results and Discussion}

The results of the population dynamics elements of the partridges populations in the hunting ground "Trubarevo" during the study period, are presented in tables 1 and 2 and graphically presented in figures 1 and 2.

Table 1. Elements of the population dynamics of grey partridge populations

\begin{tabular}{|c|c|c|c|c|}
\hline Year & $\begin{array}{c}\text { Sed/2* } \\
\text { (*Number of } \\
\text { pairs/100 ha) }\end{array}$ & Aed/100 ha & Rpg/100 ha & Crpg \\
\hline 2007 & 10.44 & 53.56 & 32.67 & 1.56 \\
\hline 2008 & 11.78 & 51.56 & 28.00 & 1.19 \\
\hline 2009 & 11.33 & 57.11 & 34.44 & 1.52 \\
\hline 2010 & 7.56 & 33.78 & 18.67 & 1.24 \\
\hline 2011 & 8.89 & 44.00 & 26.22 & 1.48 \\
\hline 2012 & 6.67 & 20.44 & 7.11 & 0.53 \\
\hline
\end{tabular}




\begin{tabular}{|l|l|l|l|l|}
\hline 2013 & 4.89 & 38.89 & 29.11 & 2.98 \\
\hline 2014 & 9.56 & 33.33 & 14.22 & 0.74 \\
\hline
\end{tabular}

Table 2. Minimal, maximal, average (X) values, standard deviation (SD) and coefficient of variation $(\mathrm{CV})$ of the population dynamics elements of the grey partridge population for the period 2007-2014

\begin{tabular}{|c|c|c|c|c|c|c|c|}
\hline Parameter & \multicolumn{2}{|c|}{$\mathrm{min} /$ year } & \multicolumn{2}{|c|}{ max/year } & \multicolumn{1}{c|}{ X } & \multicolumn{1}{c|}{ SD } & \multicolumn{1}{c|}{ CV \% } \\
\hline Crpg & 0.53 & 2012 & 2.98 & 2013 & 1.41 & 0.74 & 52.47 \\
\hline Sed/100 ha & 4.89 & 2013 & 11.78 & 2008 & 8.89 & 21.49 & 26.86 \\
\hline Rpg/100ha & 7.11 & 2012 & 34.44 & 2009 & 23.81 & 9.56 & 40.17 \\
\hline
\end{tabular}

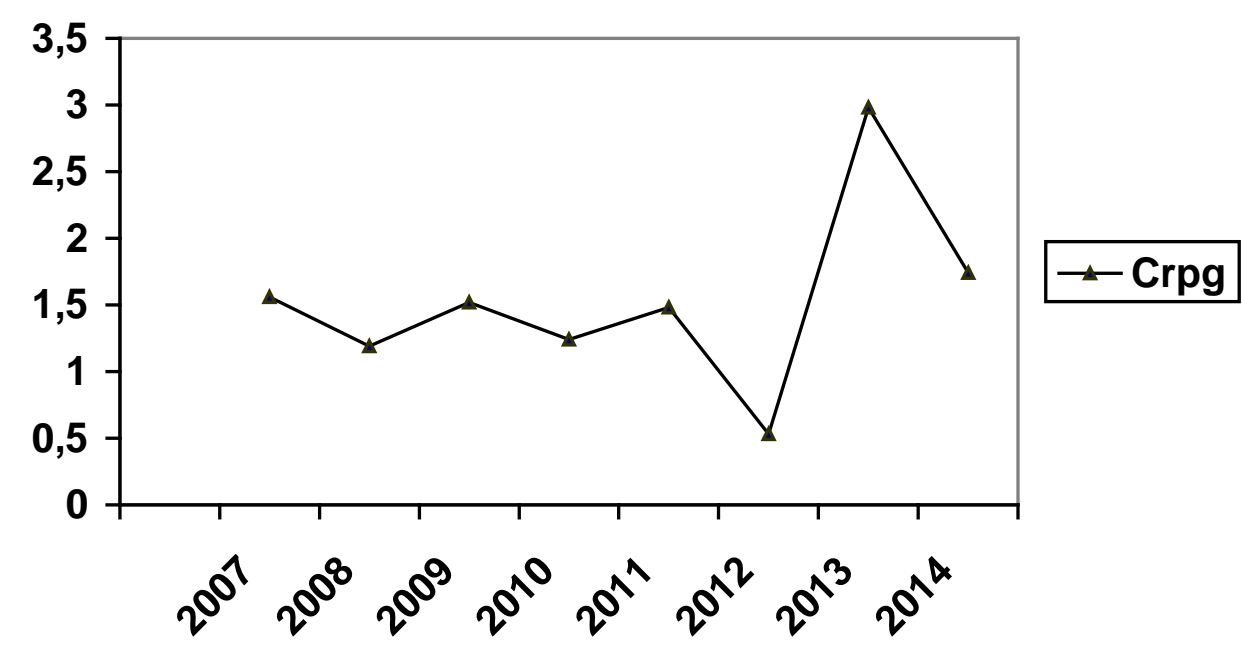

Figure 1. Graphic presentation of the coefficient of the real periodic growth of the grey partridge population

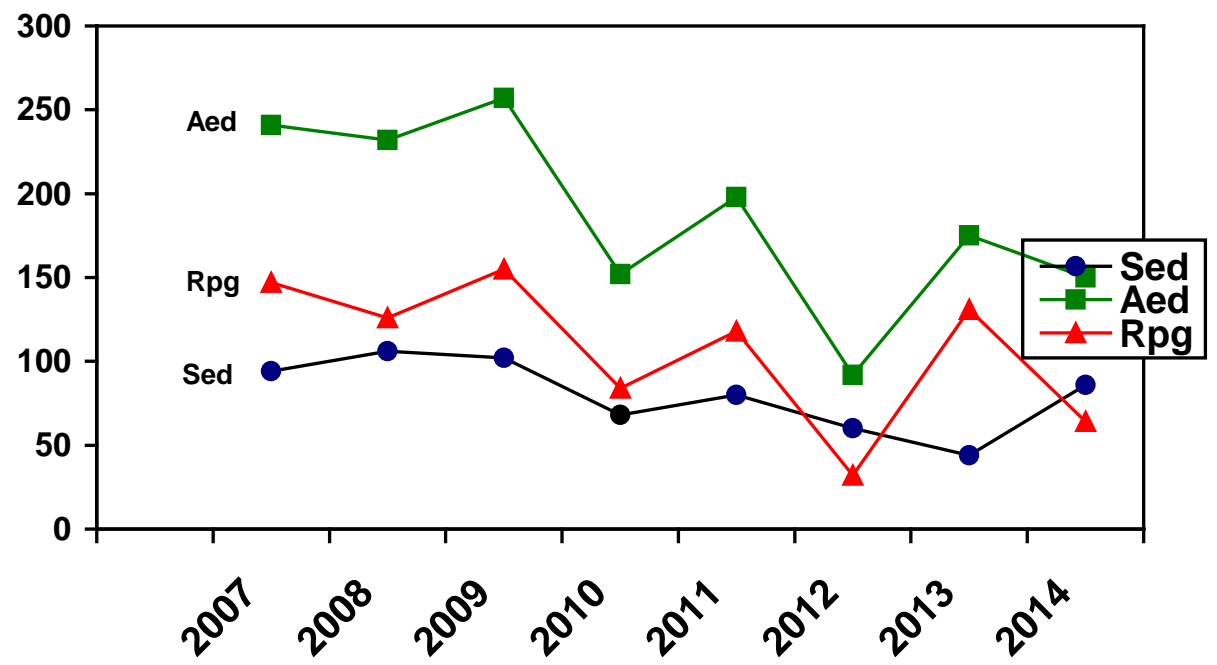

Figure 2. Graphic presentation of the population dynamics elements of the grey partridge population in absolute values 
Spring ecological density, i.e. the number of breeding pairs per 100 ha (Sed/2) at the beginning of breeding period, varies between 4.89 and 11.78, with an average value of 8.89 pairs (Table 2). After the peak registered in 2008, a decreasing trend followed until 2013 (with a minimum increase in 2011), when we also recorded the minimum value of the breeding population. The same year we registered the maximum coefficient of real periodic growth (Table 1, Figure 2). However, despite the rule that, under the same environmental conditions, lower density implies a higher coefficient of growth, that is, they're in negative correlation (Montagna \& Meriggi, 1991), we found that the correlation between these two elements is low and insignificant $(r=-0.38, p=$ 0.354).

In general, the number of pairs at the start of reproduction, as a base for the "production" of young and the size of the autumn population, varies in very wide limits. Even before the start of the drastic fall in the number of its population in Europe in the last century, spring density ranged from 3 to 46, an average of 19 birds per 100 ha in Slovakia (Hell, 1965), in Czech in two periods (19581962 and 1963-1964) the mean value of the spring number was 35.3 in the first, and 18.6 in the second period with a variation coefficient of over 50\% (Nováková \& Hanzl, 1966), in Poland, (Chlebowski \& Panek, 1985) in the period 1968 to 1985 the number of individuals fluctuated in a wide range of 2.0 - 34.5 individuals and so on. In more recent years, or at the end of the last century, the number of pairs per unit area $\left(\mathrm{km}^{2}\right)$ in Italy (Montagna \& Meriggi, 1991) was 2.1, in Poland 1.6 - 19.6 (Panek, 1997), and at the beginning of this century it dropped to $0.4-8.3$ pairs (Panek, 2005), and 0.5 - 10.5 (Panek, 2006). In France, in the early 2000s the density of as much as up to 70 pairs per 100 ha was determined at some localities, while at other ones it was at the level of only a few pairs in the same area. High and low density areas are spatially distributed as a mosaic at a small spatial scale (Bro et al., 2005).

The situation is similar in R. Macedonia, as well. The results of our study differ from the one carried out in the past only to the maximum amount, when the value of 4.63 to 17.3 were determined (Maletić, unpublished data), or 4.30 - 19.95 pairs (Trpkov, 1979). Considering the fact that the spring population density depends on the availability of nesting cover (Aebischer et al., 2003) and that the overall decline in Europe has been attributed to habitat modifications through farming specialization (e.g. a switch from mixed arable to intensive maize production) (Bro et al., 2004), it should be noted that, for the most part of the grey partridges areal in Macedonia, this is not the case. In fact, in the study area, but also in other places where its abundance was relatively satisfactory, there are mosaically distributed heterogeneous cultures on small, hedged plots, providing partridges with shelter and food during the major part of the year, so that the variability of this parameter certainly depends on other factors.

Regarding the real periodic growth per unit area in absolute terms, the minimum amount of 7.11 individuals per 100 ha was recorded the same year when the ratio of the real periodic growth was lowest, while the maximum value of 34.44 specimens was reached in the year (2009) with the largest autumn population.

The mean value of the coefficient of the real periodic growth in the population of grey partridges during the study period was 1.41 per breeding stock unit and varied in a wide range from 0.53 to 2.98. (Table 1 and 2).

During the first 5 years of research, the real periodic growth has relatively similar values (1.19 to 1.56), but in 2012 we registered the minimum value of this parameter (0.53), and already the next year we recorded the maximum value (2.98). The difference between these two values was as high as $562 \%$ compared to the minimum, which indicates a large variability of this element of the population dynamics of partridges. This is confirmed also by the high variation coefficient of $52.47 \%$. The explanation for such a low growth in 2012 lies in the fact that it was a year with heavy precipitations in the nesting period, with the coastal part of the hunting area flooded, so that a large percentage of the first nests was completely destroyed, and the minimum value of the autumn ecological density and smallest growth in absolute terms in the same year confirmed that 
the contribution of replacement clutches to population change is low (Bro et al., 2000). The determined high coefficient of the real periodic growth (2.98) next year, although not rare for the area of Macedonia (3.32 - Trpkov 1980, 3.86 - Maletić, unpublished data), besides the fact that it is possible at low density (Montagna \& Meriggi 1991 ) and high habitat potential, and although unlikely, it may be caused by immigration partridge from neighboring areas.

Such fluctuations in the value of the coefficient of the real periodic growth in the same micropopulation in two successive years, or even in two neighboring micropopulations in the same year, are very common in the population dynamics of grey partridges, which occurs as a result of high variability of many factors that determine the size of the growth, that is, it indicates the local, rather than global factors (Bro et al., 2005).

That is, in the first place, the percentage of pairs that successfully raised offspring [broodproduction rate (number of spring pairs that produce chicks)], which depends on availability of nesting cover, that is, existence of a high diversity of habitat types in the agricultural landscape and the existence of small patchy structures) (Glänzer et al., 1993; Kaiser, 1998; Panek \& Kamieniarz, 1998; Ranoux, 1998; Benton et al., 2003; Verhulst et al., 2004) and nest and incubating hen predators (Panek, 2005, 2006; Potts \& Aebischer, 1991, 1995; Bro et al., 2001; Montagna \& Meriggi, 1991; Farago et al., 2012).

Still, the chick survival, as an indicator of the real periodic growth, is a key determinant of population change (Aebischer \& Ewald, 2004; Bro et al., 2000) depending on many factors. In this sense, it has been determined that the most influential factors are the ones that act in the first weeks after hatching, stating the climate as one of the main factors (Montagna \& Meriggi, 1991; Maletić, 2007); Faragó et al. 2012) which implies the lack of animal food, then the agro-machinery and agro-chemical contamination, predators pressure and possible diseases (Blank \& Ash, 1960; Blank et al., 1967; Potts, 1980, 1986; Chlewski \& Panek, 1988; Olech, 1988; Trpkov, 1985; Potts \& Aebischer, 1995; Chamberlain et al. 2000; Benton et al. 2002; Benton, et al., 2003; Panek, 2005; Báldi \& Faragó, 2007; Kuijper et al., 2009; Maletić, 2012 etc.) Unfortunately, some of these factors can not be quantitatively expressed, and determining the significance of these effects is being further complicated by their interaction.

The lack of animal food is one of the main causes of the high mortality of the chicks, which have a diet composed of a high variety of nutritious invertebrates, without which the mortality rate up to 6 weeks of age is much higher (Browne et al., 2006). Generally, the nutrition research showed that the high protein intake from insects was crucial for feather development and survival (Southwood \& Croos, 2002). High chick mortality is directly caused by cold and rainy springs, and indirectly by the reduction in the availability of insects, which are the main food of the chicks during the first 20 days after hatching (Enck, 1987; Montagna \& Meriggi, 1991; Panek, 2005; Faragó et al. 2012).

However, the impact of climatic factors, or more correctly, some meteorological elements, are often "masked" with the average values of some of its parameters (air temperature, precipitation, humidity, etc.), which usually do not go beyond the long-term average for a wider area. Of utmost importance for the survival of grey partridge offspring are the rapid, harsh, and long-lasting changes in meteorological elements in the most critical period (May, June, July) (Potts \& Aebischer, 1995; Bro et al., 2001), especially when, as most often is the case, they operate complexly (Maletić, 2007). If low temperatures followed by heavy rainfall are prevailing at that time, losses may be as high as over 60\% (Popović et al., 1997). This is confirmed with the results of the analysis of the impact of four meteorological elements (average monthly air temperature, average monthly minimum air temperature, total precipitation and number of days with precipitation higher than $1 \mathrm{~mm}$ ) in the period of nesting and breeding of offspring, that is, in the months of May, June and July, in three different micropopulation in Macedonia, where we determined positive correlation between the first two elements and the real coefficient of the periodic growth ( $\mathrm{r}=$ from 0.62 to 0.99 ), and negative correlation between the other two elements 
and the same coefficient ( $\mathrm{r}=$ from -0.54 to -0.98 ) (Maletić, 2007). Generally, the climate with its extremes may significantly affect the size of the coefficient of the real periodic growth in a given period, but in no way can cause a permanent decline in the number of grey partridges, especially if we know that for many years the European populations of this species have survived and even increased under the same changeable weather conditions.

In addition to climatic conditions, the value of the coefficient of the real periodic growth is greatly influenced by other factors, especially the use of chemicals (pesticides) (Vickerman \& Sunderland, 1977; Panek, 2005; Browne et al. 2006; Kuijper et al. 2009; Aebischer \& Ewald, 2012 etc.), which causes reduction of weeds as shelters and lack of animal food, and also, mechanization and modernization in agricultural production (Chamberlain et al,. 2000; Benton et al. 2002; Benton et al., 2003; Bro et al., 2004), as well as predation pressure (Bro et al., 2001; Meriggi et al., 2002; Panek, 2002, 2005, 2006; Faragó et al., 2012; Aebischer \& Ewald, 2012).

Earlier researches of the real periodic growth coefficient in Macedonia also point to the great variability of this parameter. In studies of grey partridges population dynamics in three different locations in Macedonia in the late eighties and early nineties of the last century, (Maletić, unpublished data) it has been found that the average value of this parameter was 2.07 (1.02 - 3.86) with a very high coefficient of variation of $41.06 \%$. By monitoring the dynamics of grey partridges population on five typical biotope (Trpkov 1978, 1979, 1980), it has been found that this coefficient is 2.37 , with large variations, both per years $(0.98-2.52)$ in the same micropopulations, as well as per locations (0.98 - 3:32) in the same year.

In general, the methods for calculating the growth as the basis for determining the degree of exploitation of grey partridges populations, are classified into two groups:

- methods that are based on forecasting the growth and assumed population density as a function of the predetermined and graded habitat bonity and

- methods that are based on determining the real periodic growth determined in specific populations or their parts, i.e. micropopulations.

The methods of forecasting the growth, or so-called "bonity" methods, are based on the assumed densities and the determined growth coefficient corresponding to a particular habitat bonity. The growth is obtained with the spring ecological density multiplied by the given coefficient, or

Pg - periodic growth

$$
\mathbf{P g}=\mathbf{S d}{ }_{x} \mathbf{C g} \quad \text { where: }
$$

Sd - spring density of the population or micro population

Cg-coefficient of growth

These methods, which standardize the density and the periodic growth in advance, by bonity grades established on the basis of a subjective quality evaluation of the basic environmental factors that influence the survival of the actual population, have been used in the planning of the grey partridges populations management for a long time, and we are still using them in the preparation of long-term management plans (hunting plans). They share two assumptions:

- that the growth is the same every year, and

- that it's highest in the habitats with best bonity, i.e. highest density, and declines in lower bonity grades.

However, all previous studies have shown that the real periodic growth varies considerably from year to year, not only within the frames of a population, but also in the same year even in the neighboring populations. In other words, variations of the real periodic growth are so big, that any long-term norming of the exploitation based on the average values of the growth can have only approximative character (Šelmić, 1997). 
Regarding the second assumption, it must be noted that even though the habitats with better ecological conditions form populations with higher density, the simultaneous activity of intraspecies (competition in space and food) and interspecies factors (number of predators and competing species, environmental resistance, diseases, etc.) greatly distort this rule. Even if we accept that the habitat bonity is objectively ranked on the bases of ecological factors of the environment, it can not be accepted to scale the growth according to the bonity, the value of which is determined by the planned density (Šelmić, 1984). Namely, although it is clear that the natural reduction of young is higher if environmental conditions are worse (Möller, 1978), we can argue that the growth will be higher in the populations in favorable environmental conditions (better bonity), only if they are of same density. In conditions of unequal densities in areas with different environmental conditions, the growth can not depend solely and exclusively on the density, because of the impact of other "additional" factors (Šelmić, 1984).

Although this method does not take into account all the factors affecting the growth, as the nesting place, availability and structure of crops, number of predators, climatic conditions during the nesting and raising of offspring, etc., which are highly variable in different time periods, it can be used only in the preparation of long-term management plans, and only as an approximative size. However, for determination of the intensity of annual use, i.e. the size of the annual harvest rate, much more accurate data are needed, that is, it's necessary to establish the realistic periodic growth for each micropopulation individually.

The second group of methods, as a the basis for determining the size of the real periodic growth, except for the one applied in our research, used youth participation, i.e. the relationship between the young and older individuals in the population after the end of reproduction, and in two ways: by observation during the summer months (July and August) or on the basis of participation of young individuals in the shooting during the hunting season. Both methods for determining the coefficient of the real periodic growth use the same formula:

\section{Crpg $=$ Njuv/Nad where}

Crpg - Coefficient of the real periodic growth;

Njuv -Number of young individuals in the population (in the total kill);

Nad -Number of adults in the population (in the total kill)

The first method of this group determined the coefficient of the real periodic growth on the basis of the numerical strength, i.e. the number of pairs in spring and monitoring the populations immediately after the end of the reproduction, i.e. in (July and) August, in order to determine the age structure of the flocks, that is, the number of young and adult animals in them.

Using this method, in the research of grey partridges demographics in Poland (Panek, 2005) in the period 1991-2004 in 10 agricultural areas of 100-200 $\mathrm{km}^{2}$ each, located in different parts of Poland, they calculated the coefficient of the real periodic growth, i.e. the number of chicks per adult individual (Njuv/Nad), from average 2.32 (1.6 - 2.8) birds, with determined number of pairs that successfully brought offspring (brood-production rate) of $29 \%-49 \%$, average $36.8 \%$. Many other authors have also used this method (Montagna \& Meriggi, 1991; Bro et al., 2001, 2004; Faragó et al., 2012 etc.), and it has been found that the ratio juv/ad is 1.2 - 3.4 (Panek, 2006), 1.5 2.6 (Aebischer \& Ewald, 2010).

In studies conducted in the same way in Vojvodina (Ristić, 1997), the calculated coefficient of the real periodic growth varied from 2.06 to 4.46, an average 2.94. However, to calculate the total growth, and through it - the autumn numerical strength, that is, the hunting fund, the author uses the so-called coefficient of survival of adult individuals $(\lambda=0.8)$ as a fixed value, having no determined the real percentage of successful pairs (brood-production rate), which can lead to erroneous conclusions about the autumn population density, especially if we take into account the 
results of other authors who calculated that the value of this element is $68.3 \%$ in Italy (Montagna, 1991), in Poland 28\% - 75\% (Panek, 1997), or 29\% - 49\%, average 36.8\% (Panek, 2005), in Macedonia 31\% - 68\%, average 51\% (Maletić, 2006), in United Kingdom 48\% - 49\% (Ewald et al., 2012).

However, summer quantity is not a post-breeding census as in spring, but only a sample count of the grey partridge stock showing the breeding success in mid-August after crop harvest (Bro et al., 2004), and the nest size in August does not reflect the true situation of the chicks survival, because of the possible losses of the entire offspring in a single nest (Potts, 1986), so that the coefficient determined in this way may lead to erroneous conclusions.

In addition, none of the authors using this method has not counted on losses in both parts of the population (adult and juvenile) from the period of registration of the population structure (July and August) until the beginning of the hunting season (October), which, especially in the juvenile segment, in this period are not negligible, which ultimately can lead to quite inaccurately determined exploitation degree of the population or the micropopulation.

With no intention to deny the scientific importance of knowing the number of young per successful pair in the populations of grey partridges in the summer (August), as a size which indicates the amount of losses in the period of maturing, still, from a hunting aspect, the most important is to know the total growth in the population until the beginning of the hunting season, regardless the age structure in it.

Also, we have to note that, in the attempt to use the analyzed method of monitoring the partridge and determining the age structure of its population in the early morning and late afternoon hours during the summer months (July and August), we got dramatically different values compared to the applied classical counting (in test lines or on the whole area) in early fall with several participants and hunting dogs. The number determined in the summer months was only about 30\% of the one obtained in autumn, or at the end of September and beginning of October. The main reason for such differences in the registered density lies in the fact that the agricultural land in Macedonia in summer is almost completely covered with vegetation, so that the majority of the partridge population seems "invisible", while in the first half of September almost all harvest is "removed" from the field, so that the visibility of the terrain is excellent, and the young partridges are old enough and have mastered the skill of flying greater distances.

The other method from this group, as a basis for determining the size of the real periodic growth, uses the participation of young birds, that is, the ratio between young and old individuals hunted during the hunting season.

Thus, for example, Birkan in, 1977, in his study of the structure and dynamics of the grey partridge populations in France, based his calculation of autumn density on this method, but using following formulas:

$$
\begin{aligned}
& E_{2}=A_{2}+J \\
& A_{2}=\mathbf{a} \times A_{1} \\
& J=\mathbf{j} \times A_{2} \\
& E_{2}=\mathbf{a} \times A_{1}(\mathbf{1}+\mathbf{j}) \quad \text { where }
\end{aligned}
$$

$\mathrm{E}_{2}$ - autumn density;

$\mathrm{A}_{2}$ - number of adult birds in the autumn population;

$\mathrm{J}$ - number of young birds in the autumn population;

a - coefficient of survival of adults during the reproductive season (taken approximately between 0.8 and 0.9 depending on the number of predators);

$\mathrm{A}_{1}$ - spring density obtained by partial counting; 
$\mathrm{j}$ - ratio between young and adult specimens in the autumn population established in the early hunts or by direct monitoring in nature.

From the last formula follows:

$$
\begin{array}{ll}
\operatorname{Crpg}=\mathbf{a}(1+\mathbf{j}) & \text { that is } \\
\text { Crpg }=\mathbf{a}(1+\mathrm{Njuv} / \mathrm{Nad}) &
\end{array}
$$

Although losses in the segment of adults should be taken into account when calculating the growth on the basis of age structure, we believe that it should not be taken linearly, i.e. with fixed coefficients compared to the density of spring, primarily due to the large variations in growth in different years, even in the same micropopulations.

Some Polish authors (Chlewski \& Panek, 1988) consider that the coefficient of the real periodic growth determined in this way can lead to wrong conclusions about the size of the real growth, because the ratio of $\mathrm{Njuv/Nad}$ can be relatively favorable at very low, even negative growth, especially when some mortality factors have strong impacts on the population or micropopulation during the nesting period. And vice versa - Raczynski, 1973, on the basis of the research of hare micropopulation in eastern Poland, came to the conclusion that the age structure of a population or micropopulation at the beginning of the hunting season is only a variable ratio between two age categories, and that in the case of small losses of adult specimens during the reproduction season, in autumn we can note an increasement of the population density, in spite of the low number of young specimens in it.

Accordingly, we believe that this method has practical application only in cases of large samples, i.e. in mega-populations of grey partridges, and can serve as a check of the previous method, that is, for evaluation of the accuracy of the forecasted growth after a certain number of hunts or at the end of the hunting season.

Exactly for the reason that the application of this method needs a large amount of sample from shooting, using it to determine the coefficient of the real periodic growth is - due to the global threat and the status of its natural populations in most of its areal, and therefore reduced or eliminated shooting, is almost completely thrown out from use, so that the data we obtained are of earlier date.

Using this method, Mottl (1971) in the analysis of the age structure of 1658 hunted partridges in 18 hunting grounds in former Czechoslovakia, has registered huge differences in the coefficient of growth - from 0.09 to 2.45 (2722\%), average 0.68 . The extreme values of the growth were obtained on the basis of small samples of testing material (minimum of 12 and maximum of 38 specimens), which confirms our conclusion about errors that may occur using this method to determine the growth.

Many other authors have defined the growth on the basis of ad : juv ratio in the harvesting. Thus, for example, Hell, 1965, in western Slovakia, on the basis of 6064 hunted partridges, found that this ratio is average 1: 1.2 (1: 1.0 - 1: 1.7); Hell \& Bakoš in, 1970, in 9 areas in western Slovakia with 5505 hunted specimens found a coefficient growth of 1.2 (0.9 - 1.4); in Macedonia (Trpkov, 1973) on the basis of 201 birds hunted at 5 locations in Macedonia 1: 1.68; in Croatia (Andrašić, 1984 and Jakovac \& Mršić, 1989) in the researches of grey partridge micropopulation in the Hunting Society "Međumurje" - Čakovec found that this year's partridges participate in the shooting with $52 \%$, i.e. $71 \%$, which corresponds to the reproduction coefficient of 1.08, i.e. 2:45 .

Unfortunately, comparison of these values with our results is not possible due to the different approaches and methodologies in collecting and processing the data from the field. The best confirmation of the differences that might arise if both methods from this group are applied, has been given by the researches in France (Birkan, 1977), conducted in Witry - les Reims in 
France, where, according to monitoring in nature, the ratio juv: ad was 3.75, and according to analysis of the harvest it was 2.00 , or 1.9 times less.

Considering the fact that the bird populations can be efficiently managed only if the demographic mechanisms that cause change are correctly understood (Bro et al., 2004), we don't deny the scientific importance of knowing the number of young per successful pair in partridge populations in summer (August), as a measure which indicates the amount of losses in the period of maturing. Still, from hunting point of view, the most important thing to know is the total increase in the population until the beginning of the hunting season, regardless of the age structure in it.

For these reasons, for determining the real periodic growth of grey partridges micropopulations, as the most suitable method for the conditions in Macedonia, we consider that the most accurate is the one we used in our research, that is, determining the density at the beginning of the reproduction and at the end of the offspring breeding period, i.e. immediately before the start of the hunting season (the first half of March and October).

The growth determined in our investigation should not be identified with the number of young individuals in the population, because the formula that we used did not take into account the losses in the adult segment between both countings.

The growth defined in this way gives a realistic picture about the actual growth of the population or micropopulation, despite the fact that the number of young individuals is certainly greater than the value of real periodic growth obtained:

\section{Njuv > Rpg,}

which does not change anything in the final result of the value of the real periodic growth.

For the same reasons, we believe that for determining the hunting quotas the coefficient of the real periodic growth should not be equated with the ratio Njuv/Nad, but should be expressed as a quotient of the real periodic growth and the spring ecological density.

\section{Conclusion}

The average value of the spring ecological density, that is, the number of breeding pairs per 100 ha in the micropopulation of grey partridges in the hunting ground Trubarevo in the period 2007-2014 amounted to 8.89 (4.89 - 11.78), while the average real periodic growth per the same area amounted to 23.81 (7.11 - 34.44).

The coefficient of the real periodic growth has been determined at 1.41, and moved within a wide range from $0.53-2.98(\mathrm{CV}=52.47 \%)$.

Variability of the basic parameters of population dynamics, both seasonal as well as in a longer period of time, is one of the basic characteristics of all types of game, especially species with rapid change of generations, such as the grey partridge. In addition, this game inhabits biotopes heavily influenced by anthropogenic factors, where during only one reproductive season occur drastic changes of environmental conditions on which depends their survival. Therefore, the real periodic growth of its populations is perhaps the most variable category in different periods of time.

The large variations of the real periodic growth coefficient, both by years in the same population, as well as in the same year in different (even neighboring) populations, make it impossible to use the "information" about the growth in similar or neighboring populations or micropopulations, that is, they prevent the use of the multi-year average values to find the degree of exploitation of the population or micropopulation.

For the hunting science and practice it is of the utmost importance in game management, especially small game, to determine the real periodic growth, that is, the changes in population 
density during a single reproduction period (from the start of the reproduction - until the beginning of the hunting season). Knowledge of this element in different parts of its areal within a wider area, gives us the possibility of realistic planning of (micro)populations densities in certain regions, and therefore its long-term survival.

There are no universal standards for determining the real periodic growth of the partridge population or micropopulations, considering the variability of this element of population dynamics in space and time, which is the result of differences of this species population dynamics in different environmental conditions in different parts of its areal and in different time periods. Therefore, the calculations the real periodic growth in order to find the degree of exploitation of the micropopulations must be performed each year for each micropopulation. This conclusion imposes the need for constant monitoring of the most important structural elements (density and real periodic growth as a result of birth and death rates), in order to determine the degree of their rational exploitation. And the rational exploitation of grey partridges populations and micro populations is one of the most important forms of protection in the worsening ecological conditions, and the only one that is fully and exclusively in the hands of hunters.

\section{References}

1. Aebischer, N. J. \& Kavanagh, B., 1997. Grey partridge.-. In Hagemeijer, W. J. M. and M. J. Blair, editors. (Eds). The EBCC atlas of European Breeding Birds. Their distribution and abundance. Poyser. Great Britain. pp. 212-213.

2. Aebischer, N. J., Bradbury, R., Eaton, M., Henderson, I. G., Siriwardena, G. M. \& Vickery, J. A., 2003. Predicting the Response of Farmland Birds to Agricultural Change, The Game Conservancy Trust, BTO Research Report No. 289, p. 4958

3. Aebischer, N.J. \& Ewald, J.A., 2004. Managing the UK Grey Partridge Perdix perdix recovery: population change, reproduction, habitat and shooting. Ibis 146 (Suppl.2): 181-191.

4. Aebischer, N. J. \& Ewald, J. A., 2010. Grey Partridge Perdix perdix in the UK: recovery status, set-aside and shooting. Ibis, 152: 530-542.

5. Aebischer, N. J. \& Ewald, J. A., 2012. The grey partridge in the UK: population status, research, policy and prospects. Animal Biodiversity and Conservation, 35.2: 353-362.

6. Andrašić, D., 1984, Međimurci štede i čiste, Lovački vjesnik 3, Zagreb

7. Báldi, A. \& Faragó, S., 2007. Long-term changes of farmland game populations in a post-socialist country (Hungary). Agriculture, Ecosystems \& Environment, 118: 307-311.

8. Baillie, S.R., Marchant, J.H., Leech, D.I., Joys, A.C., Noble, D.G., Barimore, C., Grantham, M.J., Risely, K. \& Robinson, R.A., 2009. Breeding Birds in the Wider Countryside: Their Conservation Status 2008. BTO Research Report No. 516. Thetford: British Trust for Ornithology.

9. Benton, T.G., Bryant, D.M., Cole, L. \& Crick, H.Q.P., 2002. Linking agricultural practice to insect and bird populations: a historical study over three decades. Journal of Applied Ecology, 39, 673-687.

10. Benton, T.G., Vickery, J.A. \& Wilson, J.D., 2003. Farmland biodiversity: is habitat heterogeneity the key? Trends in Ecology and Evolution, 18, 182-188.

11. Beuković, M., Marinković, B., 1997. Efect of Changes in Vojvodina Agroecosystem on Population Number of Partridge, Proceeding book from International Symposium: Brown Hare and Partridge in present agroekosystems, Hunters Asociation of Vojvodina.

12. Blank, T. H. \& Ash, J. S., 1960. Some aspects of clutch size in the partridge (Perdix perdix). In: Proceedings of the XII-th International Ornithological Congress, 1958, pp. 118-126, Helsinki, Finland.

13. Blank, T. H., Southwood, T. R. E., \& Cross, D. J., 1967. The ecology of the partridge I. Outline of the populayion processes with particular reference to chick mortality and nest density. Journal of Animal Ecology, 36, 549-556.

14. Birkan M. G., 1977. Analyse des tableaux de chasse de perdrix (Perdix perdix L. et Alectoris rufa L.): courbes d'éclosion et dynamique des populations, plan de chasse. In: P. Pesson \& M. G. Birkan (eds), Ecologie du petit gibier et amenagement des chasses. Gauthier-Villars, Paris, pp. 137-159.

15. Birkan, M. \& Jacob, M., 1988. La Perdrix Grise. Hatier, Paris, France.

16. Bro, E., Sarrazin, F., Clobert, J. and Reitz, F., 2000. Demography and the decline of the grey partridge Perdix perdix in France Journal of Applied Ecology, 37, 432-448

17. Bro, E., Reitz, F., Clobert, J., Migot, P. \& Massot, M., 2001. Diagnosing the environmental causes of the decline in grey partridge survival in France. Ibis, 143, 120-132.

18. Bro, E., Mayot, P., Corda, E. \& Reitz, F., 2004. Impact of habitat management on grey partridge populations: assessing wildlife cover using a multisite BACI experiment. Journal of Applied Ecology, 41, 846-857.

19. Bro, E., Reitz, F. \& Landry, P., 2005. Grey partridge Perdix perdix population status in central northern France: spatial variability in density and 1994-2004 trend. Wildlife Biology, 11: 287-298.

20. Browne SJ, Aebischer NJ, Moreby SJ, Teague, L., 2006. The diet and disease susceptibility of grey partridges Perdix perdix on arable farmland in East Anglia, England. Wildlife Biol 12:3-10.

21. Burfield, I. \& van Bommel, F., 2004. Birds in Europe: Population Estimates, Trends and Conservation Status. Cambridge: Birdlife International. 
22. Chlewski, A. \& Panek, M., 1988. Population dynamics of the partridge on hunting grounds of Czempin, Poland. International Symposium Common Partridge, Poland, Proceedings, 143 - 156.

23. Chamberlain, D.E., Fuller, R.J., Bunce, R.G.H., Duckworth, J.C. \& Shrubb, M., 2000. Changes in the abundance of farmland birds in relation to the timing of agricultural intensification in England and Wales. Journal of Applied Ecology, 37, 771-788.

24. Eaton, M.A., Brown, A.F., Noble, D.G., Musgrove, A.J., Hearn, R.D., Aebischer, N.J., Gibbons, D.W., Evans, A.D. \& Gregory, R.D., 2009. Birds of Conservation Concern 3: the population status of birds in the United Kingdom, Channel Islands and Isle of Man. Br. Birds 102: 296-341.

25. Enck J. W., 1987. The effect of insect abundance on gray partridge chick survivorship in New York. In: R. O. Kimmel, J. W. Schulz \& G. J. Mitchell (eds), Perdix IV: Gray $\quad$ Partridge Workshop. Minn. Dep. of Nat. Res., Madelia, pp. 315.

26. Ewald, J. A., Potts, G. R. \& Aebischer, N. J., 2012. Restoration of a wild grey partridge shoot: a major development in the Sussex study, UK. Animal Biodiversity and conservation, 35.2: 363-369.

27. Faragó, S., 1996. Habitat in Agrarian Environment Possibilities for Sustaining Huntable and Protected Species in Hungary. International Conferece on the Sustainable Use of Biological Resources, Budapest.

28. Faragó, S., Dittrich, G., Horváth-Hangya, K. \& Winkler, D., 2012. Twenty years of the grey partridge population in the LAJTA Project (Western Hungary). Animal Biodiversity and Conservation, 35.2, 311-319.

29. Glänzer U., Havelka P., Thieme K., 1993. Rebhuhn-Forschung in Baden-Württemberg mit Schwerpunkt im Strohgäu bei Ludwigsburg - Veröffentlichungen zu Naturschutz und Landschaftspflege in Baden-Württemberg, Beiheft 70: 1993. 108 p.

30. Hell, P., 1965. K niektorym otazkam jarabic v Zapadoslovenskom kraji. Zool. listy 14, 37 - 46.

31. Hell, P., Bakoš, A., 1970. Zhodnotenie produkcie jarabic na Slovensku v roku 1968, Polnohospodarstvo XVI, 6, Nitra

32. Jakovac, M., Mršić, Z., 1989. Opstanak trčke - poljske jarebice (Perdix perdix L.) i značenje umjetnog uzgoja. Zbornik radova 3 Simpozijuma „Savremeni pravci uzgoja divljači“, Ljubljana.

33. Kaiser, W., 1998. Grey partridge (Perdix perdix) survival in relation to habitat quality. Gibier Faune Sauvage. 1998. 15. S. 157-162.

34. Kuijper, D.P.J., Oosterveld, E. \& Wymenga, E., 2009. Decline and potential recovery of the European Grey Partridge (Perdix perdix) population - a review. Eur. J. Wildl. Res. 55: 455-463.

35. Maletić, V., 2006. Parametars Fecundity in Partridge. $17^{\text {th }}$ Symposium on innovation in animal science and production, Biotehcnology in animal husbandry, vol. 22, 421 - 427, Belgrade - Zemun.

36. Maletić, V., 2007. Influence of some meteorological elements on real periodical increase of common partridge. International Symposium Sustainable forestry - problems and challenges, Ohrid, Proceedings, 108-113.

37. Maletić, V., Stojčevski, D., Beuković, D., Lavadinović, V., 2012. Elements of the population dynamics of the grey partridges (Perdix perdix L.) in suburban habitats. International symposium on hunting Modern aspects of sustainable management of game population in Zemun-Belgrade, Proceedings, 16-21.

38. Maletić, V., Stojčevski, D., Lavadinović, V., 2013. Winter mortality in the population of grey partridges (Perdix perdix L.). The $2^{\text {nd }}$ international symposium on hunting Modern aspects of sustainable management of game population in Novi Sad, Proceedings, 100-105.

39. Maletić, V., neobjavljeni podaci

40. Meriggi, A., Brangi, A., Cuccus, P \& Mazzoni Delia Stella, R., 2002. High mortality rate in are-introduced grey partridge population in central Italy, Italian Journal of Zoology, 69:1, 19-24

41. Möller, D., 1978. Der jagdlich nutzbare Zuwach des Feldhasen in der DDR und seine Beziechungen zur Fertilitat, Zbornik z medzinarodneho seminara, II del, Komarno

42. Montagna \& Meriggi, 1991. Population dynamics of grey partridge (Perdix perdix) in northern Italy, Bolletino di zoologia, 58:2, 151-155,

43. Mottl, S., 1971. Analyza vysledku pruzkumneho lovu koroptvi, Lesnictvi, 17 XLIV, 1971, 3, Praha

44. Nováková, E. \& Hanzl, R., 1966. Vliv anthropogennich zmen prostredi na početni stavy koroptvi v trebonske panvi a na Berounsku, Symposium o koroptvi, Vyzkumny ustav lesniho hospodarstvi a myslivosti, Československy myslivecky svaz.

45. Olech B., 1988. Changes in numbers of Partridges in Poland in $1964-1984$, International Symposium Common Partridge, Poland, Proceedings: $111-122$

46. Panek M., 1997. Density-dependent brood production in the Grey Partridge Perdix perdix in relation to habitat quality, Bird Study 44, 235.238

47. Panek M., Kamieniarz R., 1998. Agricultural landscape structure and density of grey partridge (Perdix perdix) populations in Poland. Gibier Faune Sauvage Game Wildlife, 15: 309-320.

48. Panek, M., 2000. Situation of grey partridge population in Poland in the years 1998-2000 (monitoring results). In: Kubiak S (ed) Zwierzyna drobna jako elementy bioróżnorodności środowiska przyrodniczego. Włocławskie Towarzystwo Naukowe, Włocławek, pp 145-154

49. Panek, M., 2002. Space use, nesting sites and breeding success of grey partridge (Perdix perdix) in two agricultural management systems in western Poland. Game and Wildlife Science 19: 313-326.

50. Panek, M., 2005. Demography of grey partridges Perdix perdix in Poland in the years 1991-2004: reasons of population decline, European Journal of Wildlife Research 2005, Volume 51, Issue 1, pp 14-18

51. Panek, M., 2006. Monitoring Grey Partridge (Perdix perdix) Populations in Poland: Methods and Results, Wildlife Biology in Practice, Vol 2, No 2, 72-78 
52. PECBMS (Pan-European Common Bird Monitoring Scheme), 2011. Population Trends of Common European Breeding Birds 2011. CSO, Prague.

53. Popović, Z., Gajić, I., 1996. Analiza promena brojnosti jarebica poljskih u našoj zemlji, Zbornik radova sa savetovanja u Prokuplju i Kikindi 1995 godine (poljska jarebica, jarebica kamenjarka, zec), Lovački savez Jugoslavije, Beograd.

54. Popović, Z., Bogdanović, V., Gajić, I., 1997. Analyze of Number in Populations of Partridge and Improvement Measures, Proceeding book from International Symposium: Brown Hare and Partridge in present agroekosystems, 107 - 113, Hunters Asociation of Vojvodina, 1997

55. Popović, Z., Beuković, M., Đorđević, N., 2008. Biotechnology in Animal Husbandry 24 (spec. issue), p. 11-23, Institute for Animal Husbandry, Belgrade-Zemun.

56. Potts, G. R., 1980. The effects of modern agriculture, nest predation and game menagement on the population ecology of partridges Perdix perdix and Alectoris rufa. Advances in Ecological Research 11, 2 - 79.

57. Potts, G. R., 1986. The Partridge: Pesticides, Predation and Conservation. Collins, London.

58. Potts, G. R. \& Aebischer, N. J., 1991. Modelling the population dynamics of the Grey Partridge: Conservation and management. In Perrins, C.M.. Lebreton. J.-D. \& Hirons. G.J.M. (eds) Bird Population Studies: Their relevance to conservation management: 373-390. Oxford: Oxford University Press.

59. Potts, G.R. \& Aebischer, N.J. 1995. Population dynamics of the Grey Partridge Perdix perdix 1793-1993: monitoring, modelling and management. Ibis 137(Suppl. 1): 29-37.

60. Putaala A., Hissa R., 1998. Breeding dispersal and demography of wild and hand-reared grey partridges Perdix perdix in Finland. Wildl. Biol., 4: 137-145.

61. Raczyňski, J., 1973. Die Gestaltung der Bestansgrosse der Hasenpopulation nach einem mehrjarigen Zyklus, Congres I.U.G.B., Stochol

62. Ranoux, F., 1998. Models to predict grey (Perdix perdix) and red-legged (Alectoris rufa) partridge spring densities in the Massif Central // Gibier Faune Sauvage. 1998. 15. P. 339-354.

63. Reitz, F., 1996. Les perdrix en 1995 dans le Nord, le Bassin parisien et le Centre: a suivre Bulletin Mensuel de l'O.N.C., 208, 2-11.

64. Risely, K., Renwick, A. R., Dadam, D., Eaton, M. A., Johnston, A., Baillie, S. R., Musgrove, A. J. \& Noble, D. G., 2011. The Breeding Bird Survey 2010. BTO Research Report 597. British Trust for Ornithology, Thetford.

65. Ristić, Z., 1997. Analyze of Partridge Real Periodic Growth, Proceeding book from International Symposium: Brown Hare and Partridge in present agroekosystems, Hunters Asociation of Vojvodina, 1997

66. Southwood, T. R. E. \& Cross, D. J., 2002. Food requirements of grey partridge Perdix perdix chicks. Wildlife Biology, 8: 175-183.

67. Šalek, M., Marhoul, P., Pintir, J., Kopecky, T., Slaby, L., 2004. Importance of unmanaged wasteland patches for the grey partridge Perdix perdix in suburban habitats, Acta Oecologica 25, 23 - 33.

68. Šelmić, V., 1984. Proučavanje zakonomernosti dinamike populacija zeca (Lepus europaeus Pall.) u Vojvodini i njihova primena u planiranju stepena racionalnog korišćenja, Doktorska disertacija, LSV, Novi Sad.

69. Šelmić, V., 1997/ Brown Hare in present agroekosystems, Proceeding book from International Symposium: Brown Hare and Partridge in present agroekosystems, Hunters Asociation of Vojvodina, 1997

70. Štasny, K. , Bejček, V., Hudec, K., 1997. Atlas hnizdniho razšireni ptaku v Česke republice 1985 - 1989. H \& H, Jinočany.

71. Tomljanović, K., Grubešić, M., Konjević, D., Tomašić, Z., 2013. Success of releasing and reintroducing grey partridge (Perdix perdix L.) into wilderness from artificial breedeing in hunting ground of central Croatia, Šumarski list, 3-4, 185190, Zagreb.

72. Трпков, Б., 1973. Просечен годишен прираст на полската еребица (Perdix perdix L.) и зачестеност на подмладокот и матичниот фонд во одделни тежински фреквенции, Годишен зборник на Земјоделско-Шумарскиот факултет, Универзитет-Скопје, Книга 25, 1972/73.

73. Трпков, Б., 1978, 1979, 1980. Извештај по темата "Утврдување и следење на матичните фондови на полските epeбици, (Perdix perdix L.) како и големината на очекуваниот отстрел на подрачјето на Македонија

74. Трпков, Б., 1985. Ловство, Привремен учебник, Универзитет Кирил и Методиј, Скопје

75. Verhulst, J., Báldi, A. \& Kleijn, D., 2004. Relation between land-use intensity and species-richness and abundance of birds in Hungary. Agriculture, Ecosystems \& Environment, 104: 465-473.

76. Vickerman, G. P. \& Sunderland, K. D., 1977. Some effects of dimethoate on arthropods in winter wheat. Journal of Applied Ecology, 14: 767-777.

Received: 29.01.2016.

Accepted: 14.09.2016.

Maletić V., Kolevska D. D., Lavadinović V., Beuković D., Stojčevski D. (2017). The real periodic population growth as a base for determining the degree of exploitation of grey partridge (Perdix perdix L.) populations in macedonia and comparative analysis of other methods used, Balkan Journal of Wildlife Research, 4(1), pp. 6-20. 